This work is licensed under a Creative Commons Attribution 4.0 International License.

Ovaj rad dostupan je za upotrebu pod licencom Creative Commons Imenovanje 4.0 međunarodna.

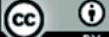

Željko PREDOJEVIĆ

UDK 398.2

Katedra slovanských filológií

004.738 .5

Filozoficka fakulta Univerzita Komenského v Bratislave

316.774

Gondova 2, 81102 Bratislava

616.2

zeljko.predojevic@uniba.sk

DOI: https://doi.org/10.29162/ANAFORA.v8i1.1

Izvorni znanstveni članak

Original Research Article

Primljeno 9. svibnja 2020.

Received: 9 May 2020

Prihvaćeno 6. kolovoza 2020.

Accepted: 6 August 2020

\title{
HUMOR KATASTROFE I INTERNETSKI MEMI U VRIJEME PANDEMIJE KORONAVIRUSA NA PRIMJERU DVAJU INSTAGRAMSKIH PROFILA
}

\section{Sažetak}

U radu se analizira humorni diskurs internetskih mema što su nastali kao reakcija na pandemiju koronavirusa. Memi se proučavaju u sklopu digitalnoga folklora kao virtualni surogati vica katastrofe s čijim žanrom imaju mnogo sličnosti. Pojavili su se odmah nakon što se pojavio i virus, tematiziraju pandemiju i novonastale životne situacije uvjetovane njome te na njih velik utjecaj imaju i medijska izvještavanja o virusu i njegovu širenju. Cilj je rada analizirati humorni diskurs internetskih mema koji je podijeljen u četiri tematsko-motivske skupine motivirane načinom pristupa temi virusa i pandemije, a zatim i pokušati uočiti kako se u njima postiže humorni učinak u usporedbi s vicem katastrofe. Istraživanje je usmjereno na internetske meme objavljene na dva instagramska profila: eroGAG i Gospodar Pršljenova. Memi su objavljeni u vrijeme početka pandemije u Europi, tj. u ožujku i travnju 2020. godine.

Ključne riječi: humor, vic katastrofe, internetski mem, digitalni folklor, koronavirus, COVID-19, pandemija, eroGAG, Gospodar Pršljenova 


\section{Uvod}

Svjetska je zdravstvena organizacija 11. ožujka 2020. godine proglasila pandemiju koronavirusa. Odmah nakon što su mediji prenijeli vijest o pandemiji, na internetskim portalima i profilima ${ }^{1}$ društvenih mreža objavljen je niz internetskih mema ${ }^{2}$ koji su nastali kao reakcija na nju, poput, primjerice: „Korona. Prvi problem kod nas koji se ne može riješiti odlaskom u Njemačku. “" Ovim će se radom analizirati takvi primjeri tekstualnih (verbalnih) internetskih mema humornog diskursa što su nastali kao reakcija na koronavirus i njegov utjecaj na čovjekov život. Promatrat će se u okviru digitalnoga folklora (usp. Blank, uvodno poglavlje; de Seta „Digital Folklore”, 1-17) kao virtualni surogati vica katastrofe. Cilj je rada analizirati humorni diskurs internetskih mema te pokušati uočiti kako se u njima postiže humorni učinak, tj. koje su sličnosti ili razlike u postizanju humornog učinka u diskursu internetskih mema i viceva katastrofe. Korpus čine memi objavljeni na dva instagramska profila - eroGAG i Gospodar Pršljenova, u ožujku i travnju 2020. godine, tj. u vrijeme početka pandemije koronavirusa u Europi.

Humor što nastaje kao reakcija na prirodne ili čovjekom uvjetovane katastrofe, u koje se može uvrstiti i pandemija koronavirusa, u stručnoj literaturi na engleskom jeziku naziva se humor of disaster (Smyth 243) ili disaster humor (Oring, „Humor in anthropology and folklore“, 196). Većina je studija usredotočena na žanr vica ${ }^{4}$ katastrofe (engl. disaster joke) što se javlja u ciklusima odmah nakon nje (usp. Dorst 181; Davies 15; Dundes 73; Oring, „Jokes and the Discourse on Disaster“, 276-88). Takvi ciklusi viceva pojavili su se, primjerice, nakon eksplozije svemirske letjelice Challanger (usp. Oring ibid.; Smyth 24360), terorističkih napada na Blizance (usp. Ellis 35-79; Kuipers 70-84; James 28-41), ali i epidemije HIV (usp. Dundes 72-81), SARS (usp. Zhang 148-70) i ebola virusa (usp. Marcus i Singer 341-56). Neki istraživači smatraju da takav

Termin profil u ovome radu odnosi se na korisnički profil na društvenim mrežama.

2 Internetski memi su slike, videoisječci ili kratki tekstovi, tipično humoristične prirode, koji se šire internetom velikom brzinom, često uz male izmjene (Lexico.com). Shifman ih definira kao: „(a) skupinu digitalnih stavki koje dijele zajedničke karakteristike sadržaja, oblika i/ili stavova; (b) koji su stvoreni sa sviješću jedni o drugima; i (c) koji kruže, imitiraju se i/ili preoblikuju na internetu među brojnim korisnicima" (11).

3 Primjeri internetskih mema prenose se kako su zapisani, bez gramatičkih ili pravopisnih korekcija i svi se nalaze na instagramskim profilima eroGAG i Gospodar Pršljenova.

4 U literaturi na engleskom jeziku uvijek se koristi riječ joke, koju je teško jednoznačno prevesti na hrvatski jezik, a mogućnosti su prijevoda šala, vic i dosjetka (usp. Marković 134-136). 
humor predstavlja svojevrsnu kolektivnu mentalnu higijenu i obrambeni mehanizam što ljudima pomaže suočiti se s katastrofalnom situacijom (usp. Blank 23; Dundes 73), dok Christie Davies smatra da takav humor nastaje samo radi zabave (33). Iako neki istraživači takav humor zbog tematske sličnosti dovode u korelaciju s bolesnim ili crnim humorom (usp. Gubanov et al. 381; Kuipers 71), Christie Davies naglašava da ih treba razlikovati, te da je humor katastrofe novija pojava koja se proširila istovremeno s masovnim medijima (16). Isprva je na nastanak i širenje takvih viceva utjecala televizija (usp. Davies 15; Oring, ibid.), a u današnje digitalno doba veliku ulogu preuzima i internet (usp. Blank xi; Davies 29-31; Kuipers 70-84).

\section{Internetski memi kao digitalni folklor i surogati klasičnih folklornih žanrova}

Prakticiranje i širenje humora prepoznato je kao jedna od središnjih točaka internetske komunikacije (Laineste i Voolaid 26). Humor je često u središtu istraživačkih interesa folklorista koji proučavaju i internetski (digitalni) folklor (usp. Baym 161-93; Blank). U studijama koje proučavaju humorni diskurs na internetu, analizirani se internetski žanrovi uglavnom dovode u suodnos s „klasičnim“ (usp. Dynel 660-88; Jambrešić Kirin 7-27) ili se napominje da se internetski žanrovi „ponašaju“ na način analogan klasičnim žanrovima u usmenom komuniciranju (Oring, Joking Asides 129-146). Estonska folkloristica Liisi Laineste u studiji o dijakronijskom pogledu na humorni diskurs napominje da on $\mathrm{u}$ folklornim izričajima nije determiniran žanrom, već da je transžanrovski, te da njegovo funkcioniranje ovisi o užem društvenom i širem kulturnom kontekstu. Napominje i da se pučki humor nalazi u svim oblicima folklora, iako se diskurs ne ograničava na tradicionalne žanrove (12).

Folkloristi i teoretičari humora usmjerili su pozornost i na humorni diskurs internetskih mema (usp. de Seta, „Pepe Goes to China“ 389-401; Dynel 660-88; Laineste 9; Laineste i Voolaid 26-49) koji su i prema rječničkoj definiciji „tipično humoristične prirode“ (Lexico.com). Iako su prema Davisonu najbrojniji oni internetski memi što se sastoje od slike i teksta, tzv. image macro (127), na području južnoslavenskog areala javlja se niz profila na društvenim mrežama (primjerice eroGAG ili Mudrolije sa Twittera) što objavljuju meme na kojima dominira tekstualna poruka. ${ }^{5}$ Internetskim memima čini ih prepoznatljiva podloga koja se

Ovakav se tip internetskih mema javlja svuda u svijetu i nisu obilježje samo južnoslavenskog areala, no u južnoslavenskom arealu instagramski profili koji plasiraju takav tip internetskih mema 
(uglavnom) ne mijenja i nije uvijek bitna za humorni učinak i shvaćanje tekstualne poruke kao što je to u slikovnim (image macro) memima. Na tu se prepoznatljivu (i neupadljivu) podlogu unosi svaki puta drukčiji (uglavnom) humorni tekst. Upravo činjenica da njima dominira tekstualna poruka, čini ih još pogodnijima za usporedbu s klasičnim folklornim žanrovima poput vica. Sličnost tih tekstualnih poruka s vicem zamjećuje se u njihovoj događajno-pripovjednoj naravi, poenti te trodijelnoj ili dvodijelnoj strukturi (usp. Užarević 73-74) što je razvidno u sljedeća dva primjera mema s instagramskog profila Gospodar Pršljenova:

1. „Ko je prdnuo?

- Ja sam

- Fuj kako te nije sramota

- Da držite preporučeni razmak od dva metra ne biste osjetili gospođo“;

2. „Moj djed nije išao u školu, otac išao $12 \mathrm{~km}$ pješke do škole, ja jedva kilometar, a moj sin izgubio daljinski." ${ }^{\text {}}$

No, ovim se radom neće uspoređivati internetski mem sa žanrom vica strukturalno. Humor na internetu nastaje i prenosi se u drukčijem okruženju nego humor u usmenoj komunikaciji, stoga se internetski žanrovi, pa tako ni internetski memi, ne trebaju izjednačavati s „klasičnim“ folklornim žanrovima. Pokušat će se ukazati na to da je internetski mem medij koji u digitalnom načinu komuniciranja prenosi surogate viceva, tj. tekstualne poruke nastale imitiranjem žanra vica, ali prilagođene internetskom komuniciranju.

Usredotočit će se na žanr vica katastrofe, u koji se mogu uvrstiti i internetski memi nastali kao reakcija na pandemiju koronavirusa. Folkloristi su početkom 21. stoljeća već upozorili na širenje viceva katastrofe internetom (usp. Davies 29-32; Kuipers 70-84), a Giselinde Kuipers ukazala je i na njihove slikovne inačice (engl. pictorial jokes) što su se širile uglavnom internetom (74), a mogu se povezati s memima. Naime, ti slikovni vicevi katastrofe stvarani su na isti način kao i internetski memi - uz pomoć programa za uređivanje fotografija, brzo

imaju znatno veći broj pratitelja nego profili koje stvaraju image macro meme. Primjerice instagramski profil Hrvatske tragedije na dan 29. travnja 2020. imao je 8143 pratitelja, eroGAG preko 60200 pratitelja, a oba profila imaju sličan pristup u stvaranju humornog diskursa koji se temelji na satiričnom prikazu hrvatske svakodnevice.

6 Budući da administrator instagramskog profila Gospodar Pršljenova prati tvitove korisnika iz svih država bivše Jugoslavije, u ovom je radu teško ograničiti se samo na hrvatski jezik. Stoga će kao primjeri poslužiti memi na svim zastupljenim jezicima na profilu, tj. na svim jezicima štokavskoga dijalekta. 
su se širili internetom, no nisu nazvani internetskim memima jer tada tema internetskog mema još nije bila dovoljno prepoznata u akademskom diskursu (usp. Miltner, „Internet memes“ 412). No, nakon epidemije ebola virusa, 2014. i 2015. godine, internetom su se proširili slikovni memi ženskoga anime lika, dizajniranog kao antropomorfni prikaz virusa nazvanog Ebola-chan. Takav su prikaz virusa Marcus i Singer okarakterizirali kao humor katastrofe (341). Vic katastrofe, osim vizualnog, ima više dodirnih točaka s internetskim memom. Šire se brzo u ciklusima, a internetski mem poznat je kao medij što se na isti fotografski predložak rapidno brzo širi internetom (Bauckhage 42). Nadalje, humor je jedan od ključnih obilježja internetskih mema (usp. Davison 122; Shifman 43; Taecharungroj i Nueangjamnong 288-301; Laineste i Voolaid 26-49), a njihov je humorni diskurs često usmjeren na društveno-političku situaciju i njezine aktere (usp. Denisova 976-94; Kulkarni 13-17; Jambrešić Kirin 7-27) ili aktualne društvene probleme (usp. Ross 975-94). Većina istraživača humora katastrofe naglašava da takav humor nastaje u velikoj mjeri kao reakcija na medijsko izvještavanje o katastrofi, a ne na sam događaj (usp. Oring „Jokes and the Discourse on Disaster“ 276-88; Dunedes 72-81; Davies 15-34; Kuipers 70-84). Internetski memi također često nastaju kao reakcija na medijska izvještavanja o aktualnim društvenim i političkim temama (usp. Milner 2357-90). Stoga ne iznenađuje činjenica da je humor koji je nastao kao reakcija na pandemiju koronavirusa jedna od aktualnijih tema humornoga diskursa internetskih mema na društvenim mrežama.

\section{Analiza internetskih mema na primjeru instagramskih stranica eroGAG i Gospodar Pršljenova}

Cilj je rada prvo tematsko-motivski analizirati humorni diskurs internetskih mema što su se pojavili kao reakcija na virus, a zatim i pokušati uočiti kako se u njima postiže humorni učinak. Virtualni su predmeti etnografije nestabilni i teško ih je pratiti (usp. Pleše i Senjković 5-6; Wittel 17-25), a ,iskustvo publike [u ovom slučaju internetskih korisnika], njezino (pred)znanje i kognitivne mogućnosti bitno utječu na doživljaj nečeg kao smiješnog“ (Tomašić 66). Zbog toga će se istraživanje usmjeriti na dva instagramska profila: eroGAG i Gospodar Pršljenova. S obzirom na to da memi imaju i identitetsku ulogu i stvaraju zajednice ljudi sličnih interesa na mreži (usp. Burgess 101-10; Miltner „There’s no Place for lulz on LOLCats"; Gal et al. 1698-714; Phillips i Milner 195-211), pretpostavlja se da i pratitelji tih profila imaju razvijen osjećaj grupne pripadno- 
sti i sličan ukus za humor. Oba profila imaju različit i specifičan način stvaranja humorna diskursa i pratitelje koji ga smatraju smiješnim, tj. zajednice korisnika što imaju sličan ukus za humor te se pretpostavlja da će mu se prilagoditi i humorni diskurs o pandemiji.

eroGag je korisnički profil na društvenoj mreži Instagram na kojem se objavljuju duhoviti internetski memi što satirično prikazuju životne navike i društvene vrijednosti Hercegovaca, s posebnim naglaskom na fraze, frazeme, uzrečice i izraze toga podneblja što se ironično-sarkastično pojašnjavaju. Profil je aktivan posljednje tri godine, a autori su anonimni. Dana 26. travnja 2020. godine instagramski profil imao je 960 objava i preko 60 tisuća pratitelja (eroGag).

Gospodar Pršljenova je korisnički profil na društvenoj mreži Instagram koji je nastao kao osobni profil Slađana Kneževića iz Nevesinja, a kasnije je prerastao te okvire i danas je jedan od popularnijih instagramskih profila južnoslavenskog areala na kojem se svakodnevno objavljuju internetski memi na svim jezicima štokavskoga dijalekta. Knežević kao administrator sam izabire sadržaj, a riječ je o uspješnim, duhovitim statusima koji su uglavnom pod pseudonimom (korisničkim imenom) objavljeni na Twitteru, a koje autor vizualno prilagodi svom instagramskom profilu, ali ne mijenja njihov tekst. Instagramski je profil 26. travnja 2020. godine imao preko 627 tisuća pratitelja i više od 10300 objava (Gospodar Pršljenova).

Sveukupno je analizirano 66 tekstualnih ${ }^{7}$ internetskih mema što su na ta dva instagramska profila objavljeni u ožujku i travnju 2020. godine. Kriteriji njihove tipologije mogu biti različiti, a u ovom su radu podijeljeni u četiri tematsko-motivske skupine motivirane načinom pristupa temi virusa i pandemije: 1 . memi što tematiziraju reakcije na pojavu virusa i njegovo (brzo) širenje; 2 . memi što su nastali kao reakcija na novonastale životne situacije uvjetovane virusom; 3. memi što temom virusa aludiraju na društveno-političku situaciju ili društvene vrijednosti zajednice, te 4 . memi što temi virusa prilaze iz aspekta popularne kulture i/ili internetskog okružja u kojem i nastaju. ${ }^{8}$ Analizirani i klasificirani korpus mema nalazi se u prilozima radu, a omjer zastupljenosti klasificiranih skupina pojedinačno za svaki profil i zajedno, prikazan je u grafu broj 1 .

Na navedenim instagramskim profilima osim tekstualnih, objavljivani su i slikovno-tekstualni (engl. image macro memes) memi koji nisu dijelom analiziranog korpusa. 


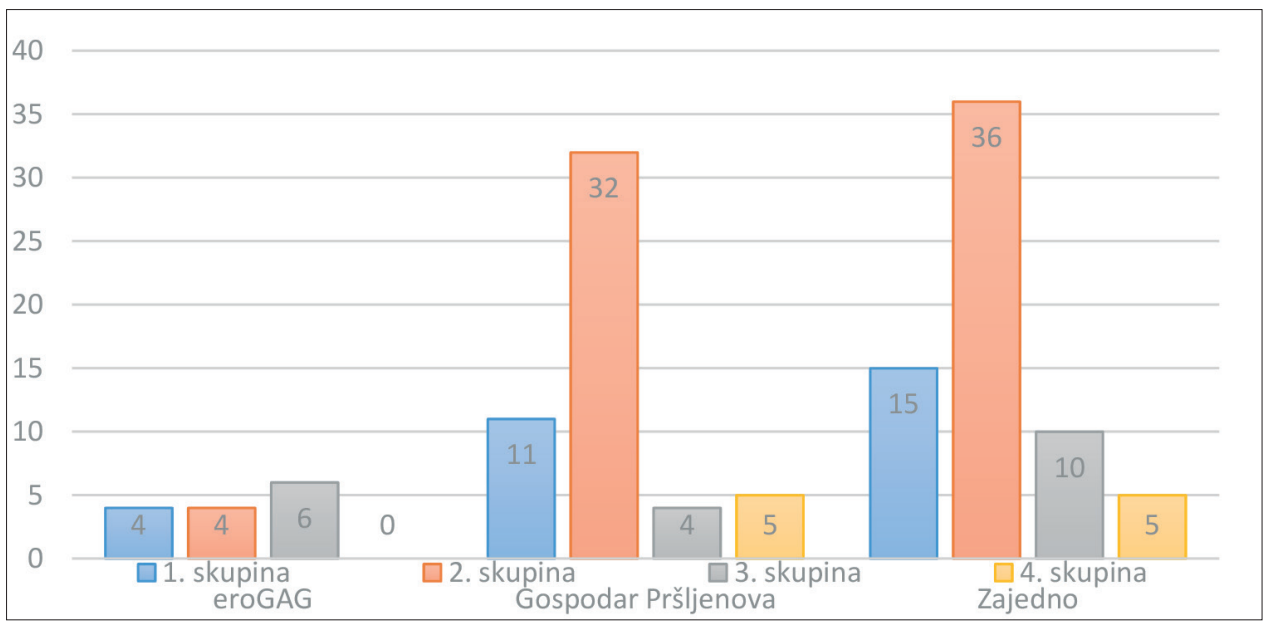

Graf br. 1. Kvantitativna analiza internetskih mema s obzirom na tematsko-motivsku tipologiju

Prema podacima iz grafa br. 1. razvidno je da je najveći broj internetskih mema što tematiziraju novonastale životne situacije uzrokovane pandemijom. Konkretno je riječ o karanteni i (samo)izolaciji („Sedmi kilogram izolacije“; „Dupe sve deblje, a živci sve tanji...“), zabrani ili preporuci starijim osobama da ne izlaze iz svojih domova („Snaha svekrvi u Crnoj Gori: Izađi jadna malo prošetaj šta se zabila u kuću“), pretjeranom kupovanju i stvaranju zaliha („Možda vi imate more ali mi imamo brasna za dve godine“; „- Tata kako si upoznao mamu? /- Bila je 2020. i ja sam imao toalet papira koliko oćeš“), zatvaranju škola i praćenju školskog programa na televiziji („Izvinjavam se ako kasnim na cas..baba je gledala seriju..“; „Službeno potvrđeno. Učenici iz Imotskog od sutra prate nastavu preko bujice.“), preporučenoj socijalnoj distanci („Zaustavio me policajac i kaže, osetim alkohol.. / - To je zato što ne poštuješ razmak od dva metra.") te upozorenjima u medijima da su dezinficijensi učinkovito sredstvo protiv zaštite od virusa („Od nakita nosila je asepsol sa pumpicom“). Internetski memi poput „Jeste primjetili da više nitko ne mrzi ponedeljak“ ili „Šta radiš sredinom juna, mogli bismo na kafu“ promatrani kroz teoriju o žanru vica katastrofe u određenoj mjeri odudaraju od opisa takvog humora u stručnoj literaturi koji se uspoređuje s tzv. bolesnim ili crnim humorom (usp. Gubanov 381; Dundes 72; Kuipers 71), a razlog je sama narav katastrofe. U vrijeme dok liječnici ne pronađu lijek protiv virusa, jedini učinkovit način da se čovjek od njega zaštiti jest disciplinarno ponašanje u skladu s uputama kriznih stožera, a jedno je od najsigurnijih mjesta obiteljski dom. Tijekom pandemije ljudi najviše 
vremena provode u svojim domovima, te su i teme o kojima se šale odraz njihove svakodnevice.

Druga je po učestalosti tema pojave virusa i njegovo (brzo) širenje. Većina istraživača humora katastrofe naglašava da takav humor nastaje više kao reakcija na medijsko izvještavanje o katastrofi negoli na samu katastrofu (usp. Davies 26; Kuipers 72; Oring, ibid. 276). To je razvidno u ovoj skupini mema gdje humorni učinak nastaje aludirajući na informacije o naglom poskupljenju dezinficijensa o kojima su izvještavali mediji (usp. Puškarić) („Ludnica oko korone se ne smiruje: Proizvođači gela za dezinfekciju ruku trljaju ruke“; „Crnogorska apoteka teamedica podigla cijenu $70 \%$ alkohola sa $6 €$ na $24 €$. jeftinije se dezinfikovat džek denijesom."). U memima se nalaze i pozdravne fraze iz zemalja što ih je virus najjače pogodio, a iz kojih se zbog toga i najviše izvještavalo $u$ medijima („Buongiorno. Čarobna riječ koja otvara sve redove na kasi.“). Najčešće se ironično komentiraju medijske objave kriznih stožera koji su često naglašavali da su „sljedeća dva tjedna najvažnija“ u sprječavanju širenja virusa (usp. Nacional.hr), a s obzirom na to da se virus ipak nije proširio prema najcrnjim predviđanjima, te se izjave banaliziraju („Sledeće dve nedelje su najkritičnije je novo od ponedeljka krećem da učim“; „Ovo sa ove DVE NEDELJE je isto kao kad ja odem na jednu rakiju“). Razvidan je utjecaj medija i na jezično oblikovanje humorna diskursa mema (usp. Sámelová i Stanková 119).

Treća je po brojnosti skupina mema što temom virusa aludira na društveno-političku situaciju ili društvene vrijednosti zajednice. Na lokalnoj se razini temom pandemije neizravno kritizira, primjerice, nepotizam („U nas ni korona nije mogla bez štele doći.“; „Obavijest SKB Mostrar: Umjesto uputnice, od sada je dovoljna i potvrda o kumstvu."). Na globalnoj razini posebice su komentirane političke odluke ili izjave bivšeg američkoga predsjednika Donalda Trumpa („Ako korona u americi nastavi ovako da se širi, napraviće meksikanci sami onaj trampov zid“; „Pa u pravu je tramp, ko popije sredstvo za dezinfekciju neće umrijet od korone"). U memima se tematiziranjem virusa aludira i na neke društvene vrijednosti poput (ne)pismenosti („Poštujete socijalnu distancu između NE i ZNAM“) ili na nemoralnost pri biranju bračnog partnera („Da ste se dobro udale sad bi sedele u dvoristu s bazenom a ne na terasi“").

Zanimljivo je da je najmanje internetskih mema što temi virusa prilaze iz aspekta popularne kulture jer ona je čest motiv humora katastrofe (usp. Oring, ibid. 284). Internetski korisnici igraju se riječima poznatih pjesama što se mogu 
povezati s praznim ulicama gradova zbog preporučene izolacije („E pa videli smo sneg u maju, sad ćemo „grad bez ljudi,, ok Severina sve si u pravu, ubedila si nas") ili parafraziraju poznate naslove popularnih televizijskih serija („-kako se zove penzos koji prekrši zabranu? / - walking đed . / jel bilo?"). Zapaža i osvrt na virtualnu realnost u kojoj memi nastaju, tj. izražava se i identitetsko pripadanje virtualnoj kulturi („Nove pratioce primam tek kad prođu karantin 14 dana, šta sad treba da mi ubace virus među 585000ljudi, ma važi“).

Kao što se i pretpostavilo, zamjećuje se značajna razlika u tematsko-motivskim skupinama što dominiraju na analiziranim profilima pojedinačno. Na profilu eroGAG humor se temelji na temi virusa što aludira na društveno-političku situaciju ili društvene vrijednosti zajednice $(42,8 \%$ primjera), dok je taj način humora na profilu Gospodar Pršljenova najmanje zastupljen (7 \%). Na profilu Gospodar Pršljenova humorni učinak nastaje uglavnom kao reakcija na novonastale životne situacije uvjetovane virusom (61\% primjera), dok je na profilu eroGAG takav način humora manje zastupljen (28,5 \%). Pojavu virusa i njegovo širenje obje stranice tematiziraju u podjednakoj mjeri. Primjeri mema što temi virusa prilaze iz aspekta popularne kulture najmanje su zastupljeni, na profilu Gospodar Pršljenova svega ih je $10 \%$, a na profilu eroGAG nije zabilježen ni jedan takav primjer. Takva razlika može se objasniti time što je tematski sadržaj profila eroGAG i inače uglavnom satira društvenih vrijednosti i društveno-političke situacije zajednice, a humor je rijetko koncentriran na pojedinca. Stoga se na njemu javljaju memi, poput već navedenog: „Korona. Prvi problem kod nas koji se ne može riješiti odlaskom u Njemačku." Pojedinac koji se obraća zajednici pak češći je pristup što se koristi na profilu Gospodar Pršljenova, stoga se i humor vezan uz temu pandemije gradio tim putem. Na profilu Gospodar Pršljenova internetskoj zajednici uglavnom se obraćaju pojedinci pod pseudonimom (korisničkim imenima s Twittera poput Brufenka) s osobnim doživljajem novonastale situacije. Stoga su češće teme kako pojedinac proživljava karantenu ili (samo)izolaciju poput mema: „Deseti dan izolacije, pola čojek pola kauč“ Dakle, pristup temi koronavirusa ovisi i o profilu društvene mreže na kojem se pojavljuju memi, tj. tema utjecaja virusa na čovjekov život prilagođena je kolektivnom identitetu skupine kojoj je mem upućen. 


\section{Humorni učinak $u$ vicevima katastrofe $i$ internetskim memima}

Humor je kompleksan fenomen i teško ga je jednoznačno definirati (Attardo 3), stoga se češće govori o teorijama humora, a i tada je humorni učinak teško objasniti samo jednom od njih (Krikmann 28). Većina se teoretičara vica katastrofe slaže da se humorni učinak u njima zasniva na inkongruentnosti (usp. Davies 13-14; Kuipers 71; Oring, ibid. 287). Inkongruentnost (nepodudarnost, proturječnost) (engl. incongruity) mnogi su teoretičari humora prepoznali kao njegovo ključno mjesto (usp. Oring Joking Asides 16-33; Ritchie 313-32; Prodanović Stankić 39). Nepodudarnost predstavlja nesklad između očekivanog i neočekivanog što se razrješava tako da izaziva iznenađenje i humor (Prodanović Stankić 39). Osnovni je mehanizam viceva katastrofe humorni sudar (engl. humorous clash) pri kojem se katastrofa na šaljiv način povezuje s temom za koju se smatra da je nespojiva s tako ozbiljnim događajem (Kupiers 71). U humornom diskursu analiziranih internetskih mema najčešće je riječ o nepodudarnosti u ozbiljnosti situacije uzrokovane pandemijom i nekakvih banalnih, pandemiji neprimjerenih situacija poput, primjerice: „Policija upozorava da u autu ne ostavljate vrijedne stvari kao što su konzerve, makarone, toalet papir“. Razrješenje nepodudarnosti postiže se i parafraziranjem („Tko drugom kopa izolaciju sam u nju pada“), aludiranjem („Sezona 2020 je lošija od zadnje sezone gejm of trones“; „Penzionere hvataju po ulici ko pokemone“) te njihovim kombinacijama („-kako se zove penzos koji prekrši zabranu? / walking đed. / jel bilo?“; „E pa videli smo sneg u maju, sad ćemo „grad bez ljudi,, ok Severina sve si u pravu, ubedila si nas"). U memima se nalaze evocirani elementi usmene tradicije, tekstovi popularnih pjesama ili nazivi televizijskih serija koji su općepoznati, no primjenjuju se na posve neočekivano iskustvo, izaziva se kratki spoj, a time i humorni učinak (Bagić 26, 234). Drugi je način razrješenja nepodudarnosti i stvaranja humornog sudara povezivanje katastrofe s nekim neprimjerenim temama (Kuipers 71), što se $u$ analiziranim memima pojavljuje u znatno manjoj čestotnosti. Primjerice javljaju se memi što se mogu okarakterizirati rasističkima jer aludiraju na kinesku ishranu na tzv. mokrim tržnicama koja je bila povezivana s nastankom virusa („Ovaj šišmiš nije dobro kuvan / - Ajde boga ti neće svijet propast ako nije“). Osim toga, javljaju se vicevima imanentne teme odnosa svekrve i snahe, te punice i zeta, a takav aktualizirani tematsko-motivski diskurs mema može se promatrati i intertekstualno (usp. Laineste i Voolaid 26-49). Eksplicitniji su nego u usmenom humoru („Kada bi morali žrtvovat jednu osobu zbog corone, navedite koga i zašto baš svekrva?“; „Snaha svekrvi 
u Crnoj Gori: Izađi jadna malo prošetaj šta se zabila u kuću“), a razlog tomu, prema Blanku, može biti i u njihovoj anonimnosti te se internetski korisnici koji ih stvaraju ne moraju suočiti s izravnom reakcijom zajednice (xvii).

U većini je internetskih mema narativnost tekstualne poruke minimalna, poput u memima „Sedmi kilogram izolacije“ ili „Sve će ovo bura rašćerat.“ U njima se humorni učinak ne može postići bez konteksta koji memi dobivaju objavljivanjem na točno određenim mrežnim stranicama, ili u ovom slučaju na instagramskim profilima, gdje i ostali memi tematiziraju pandemiju virusa. Kontekst, osim mjesta objavljivanja, memima osigurava i podloga na kojoj su napisani. Naime, analizirani internetski memi sastoje se od različitih tekstualnih poruka napisanih na istoj neupadljivoj podlozi (vidi sliku 1).

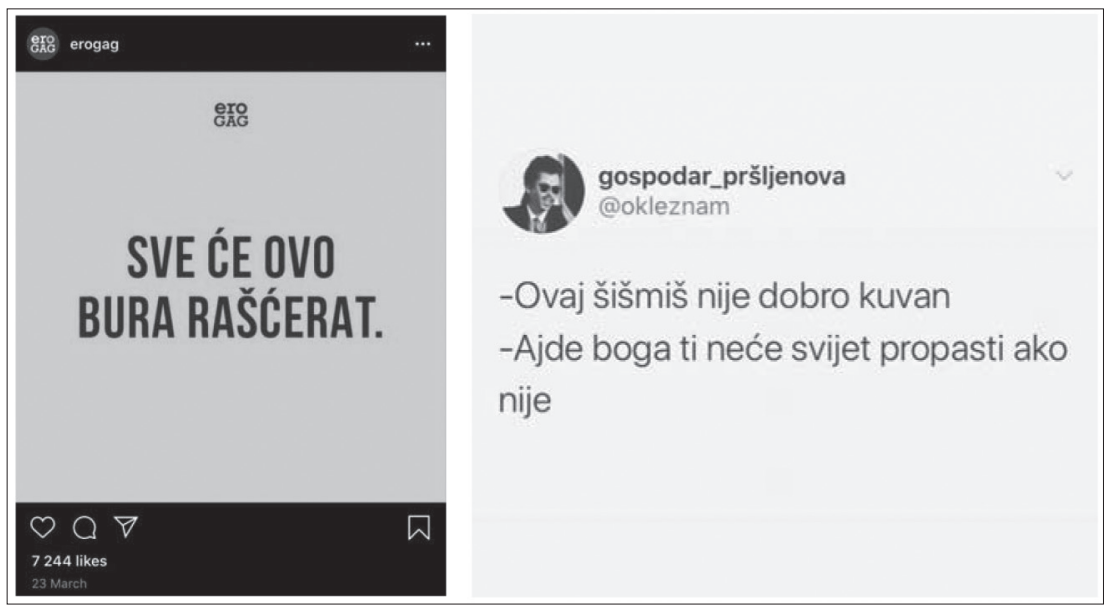

Slika br. 1. Primjeri internetskih mema Izvori: eroGAG i Gospodar Pršljenova

Iako slikovna podloga nije uvijek ključna za razumijevanje šaljivoga teksta, nije ni zanemariva. Ona analizirane internetske meme stavlja u kontekst, ukazuje na njihovu pripadnost određenoj zajednici i vizualna je predstava identiteta - što samog instagramskog profila, ali i zajednice korisnika koji ga prate. Primjerice, internetskim memima „Sve će ovo bura rašćerat“ ili „Tko drugom kopa izolaciju sam u nju pada“, prepoznatljiva podloga instagramskog profila eroGAG daje dodatni kontekst koji je bitan u konačnom humornom učinku. Iako se ovdje radi samo o jednom primjeru parafrazirane poslovice, na profilu eroGAG humor se i inače gradi na takav način da se parafraziraju, ironično-sarkastično komentiraju ili objašnjavaju pučke fraze, frazemi, uzrečice, izrazi i sl. Slikov- 
na se podloga može smatrati izvanjezičnim elementom verbalnog humora koja utječe na stvaranje i razumijevanje danog oblika humora (Prodanović Stankić 66). Humor sadrži specifične elemente kulture ili je zasnovan na stereotipima koji nisu smiješni ili poznati predstavnicima drugih kultura (ibid. 73).

\section{Zaključno}

U ovom je radu analiziran humorni diskurs internetskih mema što su se pojavili kao reakcija na koronavirus na instagramskim profilima eroGAG i Gospodar Pršljenova u ožujku i travnju 2020. godine. Zaključiti se može da se analizirani internetski memi mogu povezati sa žanrom vica katastrofe ponajprije tematskim okvirom, tj. tematiziranjem katastrofe na humorističan način. Osim toga, u oba se žanra zamjećuje njihova nagla pojava odmah nakon katastrofalne situacije, brzo se šire, te na njih velik utjecaj imaju i medijska izvještavanja o katastrofi koja su češće tematizirana, nego sama katastrofa. No, ne može se zaključiti da su tematizirani memi zaista i vicevi katastrofe. Humor na internetu nastaje i prenosi se u drukčijem okruženju nego humor u usmenoj komunikaciji, stoga se internetski žanrovi, pa tako ni analizirani internetski memi, ne trebaju izjednačavati s „klasičnim“ folklornim žanrovima. No zbog toga što se „ponašaju“ kao vicevi katastrofe u usmenom komuniciranju, mogu se promatrati kao njihovi virtualni surogati koji su prilagođeni internetskom okruženju i digitalnom načinu komuniciranja, gdje uz tekst važnu ulogu ima i virtualni prostor, tj. konkretno mjesto na kojem su objavljeni i podloga na kojoj su napisani, a što im daje kontekst.

Analizirani internetski memi podijeljeni su u četiri tematsko-motivske skupine koje su analizirane pojedinačno za oba instagramska profila, ali i zajedno, kako bi se uvidjelo koje su teme najčešće. Zaključeno je da je najveći broj mema što su nastali kao reakcija na novonastale životne situacije uvjetovane virusom, poput karantene ili (samo)izolacije. Druga skupina po čestotnosti tematizira reakcije na pojavu virusa i njegovo (brzo) širenje. Treća temom virusa aludira na društveno-političku situaciju ili društvene vrijednosti zajednice, a najmanje je onih mema što temi virusa prilaze iz aspekta popularne kulture $\mathrm{i} / \mathrm{ili}$ internetskog okružja u kojem i nastaju. U pojedinačnoj analizi za svaki profil zasebno, zaključeno je da među njima postoje veće razlike. Profil eroGAG humor gradi na skupini mema što temom virusa aludiraju na društveno-političku situaciju ili društvene vrijednosti zajednice (42,8 \% primjera), a profil Gospodar Pršljenova na temi pojedinca u novonastalim životnim situacijama uvjetovanim pande- 
mijom (61 \% primjera). Prema tim rezultatima može se zaključiti da je tema utjecaja virusa na čovjekov život prilagođena iskustvu publike (ili internetskih korisnika koji prate određeni profil), njezinom predznanju i očekivanjima, tj. prilagođena je kolektivnom identitetu skupine kojoj je mem upućen.

Prve društveno-humanističke studije o koronavirusu upozoravaju i na važnost humora za mentalno zdravlje $u$ vrijeme pandemije, te naglašavaju da $u$ tome ulogu imaju i internetski memi (usp. Thelwall i Thelwall). Folkloristi se s tom činjenicom slažu (usp. Blank 23; Dundes 73) ili naglašavaju da takav humor nastaje samo radi humora (Davies 33). S obzirom na tematsko-motivsku analizu u ovom radu, ne može se donijeti jednostran zaključak što je uloga i ovog tematskog vala humora katastrofe, ali se može zaključiti da teme kojima se aludira na virus sežu od društveno-političkih do onih za razbibrigu.

\section{Literatura}

Attardo, Salvatore. Linguistic Theories of Humor. Mouton de Greuyter, 1994.

Bagić, Krešimir. Rječnik stilskih figura. Školska knjiga, 2012.

Baym, Nancy K. „Izvedbe humora u računalno posredovanoj komunikaciji.“ Etnografije interneta, uredile Iva Pleše i Reana Senjković, Institut za etnologiju i folkloristiku, 2004, str. 161-93.

Bauckhage, Christian. „Insights into Internet Memes.“ Proceedings of the Fifth International AAAI Conference on Weblogs and Social Media. https://pdfs.semanticscholar.org/ eaee/cfe9501e96b78b6c6fc073d0822c9c0c7b13.pdf. Pristupljeno 12. travnja 2020.

Blank, Trevor J. The Last Laugh. Folk Humor, Celebrity Culture, and Mass-Mediated Disasters in the Digital Age. The UP of Wisconsin, 2013.

Burgess, Jean. „All Your Chocolate Rain Are Belong to Us? Viral Video, YouTube and The Dynamics of Participatory Culture." Video Vortex Reader. Responses to YouTube, uredili Lovink Geert i Sabine Niederer, Institute of Network Cultures, 2008, str. 101-10.

Davies, Christie. „Jokes that follow Mass-Mediated Disasters in a Global Electronic Age.“ Of Corpse: Death and Humor in Folklore and Popular Culture, uredio Peter Narváez, UP of Colorado, 2003, str. 15-34.

Davison, Patrick. 2012. „The Language of Internet Memes.“ The Social Media Reader, uredio Michael Mandiberg, NYUP, 2012, str. 120-34.

de Seta, Gabriele. „Pepe Goes to China, or, the Post-Global Circulation of Memes.“ Post memes: Seizing the memes of production, uredili Alfie Bown i Dan Bristow, Punctum books, 2019, str. 389-401. http://library.oapen.org/handle/20.500.12657/23830. Pristupljeno 25. travnja 2020.

---. „Digital Folklore.“ Second International Handbook of Internet Research, uredili Jeremy Hunsinger et al., Springer, 2020, str. 1-17. 
Denisova, Anastasia. „Democracy, protest and public sphere in Russia after the 2011-2012 anti-government protests: digital media at stake.“ Media, Culture \& Society, sv. 39, br. 7, 2017, str. 976-94.

Dundes, Alan. „At Ease , Disease - AIDS Jokes as Sick Humor.“ American Behavioral Scientist, sv. 30, br. 3, 1987, str. 72-81.

Dorst, John. „Tags and Burners, Cycles and Networks: Folklore in the Telectronic Age.“ Journal of Folklore Research, sv. 27, br. 3, 1990, str. 179-90.

Dynel, Marta. „"I Has Seen Image Macros!” Advice Animals Memes as Visual-Verbal Jokes." International Journal of Communication, sv. 10, br. 29, 2016, str. 660-88.

Ellis, Bill. „A Model for Collecting and Interpreting World Trade Center Disaster Jokes.“ Of Corpse: Death and Humor in Folklore and Popular Culture, uredio Peter Narváez, UP of Colorado, 2003, str. 35-79.

eroGAG. https://www.instagram.com/erogag/. Pristupljeno 26. travnja 2020.

Gal, Noam et al. „'It Gets Better'. Internet Memes and the Construction of Collective Identity." New Media \& Society, sv.18, br. 8, 2015, str. 1698-714.

Gospodar Pršljenova. https://www.instagram.com/gospodar_prsljenova/. Pristupljeno 26. travnja 2020.

Gubanov, Nikolay N. et al. „Factors of Black Humor Popularity.“ Proceedings of the International Conference on Contemporary Education, Social Sciences and Ecological Studies, uredili Irina Solovjeva et al., Atlantis Press, 2018, str. 379-83.

Jambrešić Kirin, Renata. „Dance Kolinda Yes Kolinda Yes Kolinda Dance“: Humorous Representations of the Croatian President.“ Narodna umjetnost, sv. 54, br. 1, 2017, str. $7-27$.

James, Aju Basil. „Humour as Resistance: Disaster Humour in Post-9/11 United States.“ The European Journal of Humour Research, sv. 2, br. 3, 2014, str. 28-41.

Krikmann, Arvo. „Contemporary Linguistic Theories of Humour.“ Folklore: Electronic Journal of Folklore, 33, 2006, str. 27-58.

Kuipers, Giselinde. "'Where Was King Kong When We Needed Him?” Public Discourse, Digital Disaster Jokes, and the Functions of Laughter after 9/11. "The Journal of American Culture, sv. 28, br. 1, 2005, str. 70-84.

Kulkarni, Anushka. „Internet Meme and Political Discourse: A Study on the Impact of Internet Meme as a Tool in Communicating Political Satire." Journal of Content, Community \& Communication Amity School of Communication, sv. 6, br. 3, 2017, str. $13-17$.

Laineste, Liisi i Piret Voolaid. „Laughing Across Borders: Intertextuality Of Internet Memes." The European Journal of Humour Research, sv. 4, br. 4, 2016, str. 26-49.

Laineste, Liisi. „From Joke Tales to Demotivators. A Diachronic Look at Humorous Discourse in Folklore." Traditiones, sv. 45, br. 3, 2016, str. 7-25.

Lexico.com. https://en.oxforddictionaries.com/definition/meme. Pristupljeno 17. travnja 2020 . 
Marcus, Oliva Rose i Merrill Singer. 2017. „Loving Ebola-chan: Internet memes in an epidemic." Media, Culture and Society, sv. 39, br. 3, 2017, str. 341-56.

Marković, Ivan. „Jezikoslovci i vic: Slučaj Charlesa F. Hocketta.“ Humor u svakodnevnoj komunikaciji, uredile Renata Jambrešić Kirin et al., Institut za etnologiju i folkloristiku, 2018, str. 133-61.

Milner, Ryan M. „Pop Polyvocality: Internet Memes, Public Participation, and the Occupy Wall Street Movement.“ International Journal of Communication, 7, 2013, str. 235790.

Miltner, Kate M. „'There's no Place for lulz on LOLCats'. The Role of Genre, Gender, and Group Identity in the Interpretation and Enjoyment of an Internet meme." First Monday, 2014, http://firstmonday.org/ojs/index.php/fm/article/view/5391/4103 Pristupljeno 20. travnja 2020.

---. „Internet memes.“ The Sage Handbook of Social Media, uredili Jean Burgess et al., SAGE Publications Ltd., 2018, str. 412-28.

Nacional. „Capak pojasnio zašto su sljedeća dva do tri tjedna ključna“. Nacional.hr, 4. travnja 2020., https://www.nacional.hr/479058-2/. Pristupljeno 2. svibnja 2020.

Oring, Elliott. „Jokes and the Discourse on Disaster.“ The Journal of American Folklore, sv. 100, br. 397, 1987, str. 276-86.

---. „Humor in Anthropology and Folklore.“ The Primer of Humor Research, uredio Victor Raskin, Mouton De Gruyter, 2008, str. 183-211.

---. Joking Asides: The Theory, Analysis, and Aesthetics of Humor. Universety Press of Colorado, 2016.

Phillips, Whitney i Ryan M. Milner. „Decoding Memes. Barthes’ Punctum, Feminist Standpoint Theory, and the Political Significance of \#YesAllWomen." Entertainment Values, uredio Stephen Harrington, Palgrave Macmillan, 2017, str. 195-211.

Pleše, Iva i Reana Senjković. „Etnografije interneta.“ Etnografije interneta, uredile Iva Pleše i Reana Senjković, Institut za etnologiju i folkloristiku, 2004, str. 5-16.

Prodanović Stankić, Diana. Verbalni humor u engleskom i srpskom jeziku. Filozofski fakultet Novi Sad, 2016.

Puškarić, Ksenija. „Cijene osnovnih proizvoda lete u nebo! Državni inspektorat na terenu.“ Lider, 7. travnja 2020. https://www.lider.media/poslovna-scena/hrvatska/cijene-osnovnih-proizvoda-lete-u-nebo-drzavni-inspektorat-na-terenu-130849. Pristupljeno 22. travnja 2020.

Ritchie, Graeme. „Variants of Incongruity Resolution.“ Journal of Literary Theory, sv. 3, br. 2, 2009, str. 313-32.

Ross, Andrew S. „Internet Memes, Media Frames, and the Conflicting Logics of Climate Change Discourse." Environmental Communication, sv. 13, br. 7, 2019, str. 975-94.

Sámelová, Anna i Mária Stanková. „Some Ideas on Facts and no Facts within Media Language." European Journal of Media, Art and Photography, sv. 6, br. 2, str. 118-23.

Shifman, Limor. Memes in Digital Culture. The MIT Press, 2013. 
Smyth, Willie. „Challenger Jokes and the Humor of Disaster.“ Western Folklore, sv. 45, br. 4, 1986, str. 243-260.

Taecharungroj, Viriya i Pitchanut Nueangjamnong. „Humour 2.0: Styles and Types of Humour and Virality of Memes on Facebook." Journal of Creative Communications, sv. 10, br. 3, 2015, str. 288-302.

Thelwall, Mike i Saheeda Thelwall. „Retweeting for COVID-19: Consensus building, information sharing, dissent, and lockdown life.“ 2020, https://arxiv.org/abs/2004.02793 Pristupljeno 2. svibnja 2020.

Tomašić, Josipa. „Humor u kuhinji: što je smiješno u natpisima na zidnjacima.“ Humor u svakodnevnoj komunikaciji, uredile Renata Jambrešić Kirin et al., Institut za etnologiju i folkloristiku, 2018, str. 61-80.

Užarević, Josip. Književni minimalizam. Disput, 2012.

Wittel, Andreas. „Etnografije u pokretu. Od terena do mreže i interneta.“ Etnografije interneta, uredile Iva Pleše i Reana Senjković, Institut za etnologiju i folkloristiku, 2004, str. 17-26.

Zhang, Hong. „Making light of the Dark Side. SARS Jokes and Humor in China." SARS in China: Prelude to Pandemic?, uredili Arthur Kleinman i James L. Watson, Standford UP, 2006, 148-70.

\section{Prilog 1. Popis internetskih mema}

\section{Internetski memi nastali kao reakcija na pojavu virusa i njegovo brzo širenje}

\section{eroGAG}

1. U Hercegovini je tolika panika zbog koronavirusa da je stupanj pripravnosti povećan s „Ne daj, Bože! na „Odstupi, đavle!“

2. Korona. Prvi problem u nas koji se ne može riješiti odlaskom u Njemač$\mathrm{ku}$.

3. Buongiorno. Čarobna riječ koja otvara sve redove na kasi.

4. Ludnica oko korone se ne smiruje: Proizvođači gela za dezinfekciju ruku trljaju ruke.

\section{Gospodar Pršljenova}

1. Ako ovaj virus udje u Sloveniju..pobice pola Bosne

2. Ovo je prvi puta $u$ istoriji da original dolazi iz Kine a falš iz Milana

3. Ovaj šišmiš nije dobro kuvan Ajde boga ti neće svijet propast ako nije 
4. Sledeće dve nedelje su najkritičnije je novo od ponedeljka krećem da učim

5. Ovo sa ove DVE NEDELJE je isto kao kad ja odem na jednu rakiju

6. Meni su celi život naredne dve nedelje kritične

7. Kada bi morali žrtvovat jednu osobu zbog corone, navedite koga i zašto baš svekrva?

8. Kako ne izmisle neki virus koji samo nagriza salo?!

9. Dajte neki drugi virus ovaj smo ispucali sve fore

2. Internetski memi nastali kao reakcija na novonastale životne situacije uvjetovane virusom

eroGAG

1. Policija uvodi dodatne mjere na graničnim prijelazima zbog korone. Nakon pitanja: „Išta za prijavit?“, postavljaju dodatno pitanje: „Sigurno ništa?"

2. Službeno potvrđeno. Učenici iz Imotskog od sutra prate nastavu preko bujice.

3. Češće komuniciram ja s punicom nego krizni stožer HNŽ-a s javnosti.

4. Da mi je vidit frizera i samo mu jedno reć: Ko i zadnji put.

\section{Gospodar Pršljenova}

1. Policija upozorava da u autu ne ostavljate vrijedne stvari kao što su konzerve, makarone, toalet papir

2. Bila bi fora da sad kažu da neće biti struje, pa da ovi što su potrpali hranu u zamrzivače krenu da jedu dok se ne prosoru. Zalihe toalet papira da dobiju svrhu

3. Crnogorska apoteka teamedica podigla cijenu $70 \%$ alkohola sa $6 €$ na 24 $€$. jeftinije se dezinfikovat džek denijesom.

4. Ovo je pravi trenutak da sad Vi kažete roditeljima: HOĆEŠ DA MI MILICIJA DOLAZI NA VRATA ZBOG TEBE??!!

5. Pobjegao danas sa časa (Prebacio kanal na pink)

6. Moj djed nije išao u školu, otac išao $12 \mathrm{~km}$ pješke do škole, ja jedva kilometar, a moj sin izgubio daljinski.

7. Izvinjavam se ako kasnim na cas..baba je gledala seriju..

8. Možda vi imate more ali mi imamo brasna za dve godine 
9. Snaha svekrvi u Crnoj Gori: Izađi jadna malo prošetaj šta se zabila u kuću

10. Jeste primjetili da više nitko ne mrzi ponedeljak

11. Sedmi kilogram izolacije

12. Od nakita nosila je asepsol sa pumpicom

13. - Šta ne nosiš masku?

- Pa nisam bio u ugroženim područjima, nisam zarazan

- Al ružan si, treba, nosi masku molim te

14. Mene je malo sramota reći ali ja ni do sad nisam nikud išla

15. Sine sjutra nema škole tata nije platio račun za kablovsku

16. - Majko đe si pošla!?

- Napolje

- Ne može napolje reko sam!!!

- Ali kako može Anica!?

- Ne zanimaju mene tuđe majke!

17. Polako se spajaju obrve priroda se oporavlja

18. - Tata kako si upoznao mamu?

- Bila je 2020. i ja sam imao toalet papira koliko oćeš

19. Deseti dan izolacije, pola čojek pola kauč

20. - gde si?

- : jedi govna!

21. Još malo pa mjesec dana izolacije, nedostaje mi teretana nisam bio u njoj sad će 4 godine

22. - Ko je prdnuo?

- Ja sam

- Fuj kako te nije sramota

- Da držite preporučeni razmak od dva metra ne biste osjetili gospođo

23. Tačno će prvi dan kad završi pandemija i puste nas sve napolje biti ponedeljak

24. Ko da mi je 16 godina, kosa malo poduža i ne smijem nikud iskuće

25. Najveći gubitnici korona krize su jakne za prelazni period

26. „Panda u proseku jede 12 puta dnevno, mi u karantinu jedemo isto toliko, zato se ovo zove pandemija"

27. Zaustavio me policajac i kaže, osetim alkohol..

To je zato što ne poštuješ razmak od dva metra. 
28. Mogućnost da ćeš se ljubiti s nekim nije vrijedna toga da ćevape naručiš bez luka

29. Dupe sve deblje, a živci sve tanji...

30. „Alkohol vam neće pomoći u karantinu“ ali ne pomaže ni voda majko sa korita ivanova

31. Dobro jutro. Kaže voditeljka vremenske prognoze popodne mogući pljuskovi ponesite kišobrane. Gde da ga ponesem u špaiz

32. Sad me strah da ne odgode i Novu godinu

33. Šta radiš sredinom juna, mogli bismo na kafu

3. Internetski memi što aludiraju na društveno-političku situaciju i društvene vrijednosti

eroGAG

1. Obavijest SKB Mostrar: Umjesto uputnice, od sada je dovoljna i potvrda o kumstvu.

2. U nas ni korona nije mogla bez štele doći.

3. Valjalo bi sad i kuću okrečit da ne uzimam poslije godišnji.

4. Sve će ovo bura rašćerat.

5. Ižinjavat. Postavljat visoko-komplicirane i teško ispunjive zahtjeve.

6. Tko drugom kopa izolaciju sam u nju pada.

\section{Gospodar Pršljenova}

1. Korona da bi ušla u BiH treba joj zeleni karton

2. Da ste se dobro udale sad bi sedele $u$ dvoristu s bazenom a ne na terasi

3. Poštujete socijalnu distancu između NE i ZNAM

4. Pa u pravu je tramp, ko popije sredstvo za dezinfekciju neće umrijet od korone

5. Ako korona u americi nastavi ovako da se širi, napraviće meksikanci sami onaj trampov zi

Internetski memi što aludiraju na popularnu kulturu ili internetsko okruženje

\section{Gospodar Pršljenova}

1. Nove pratioce primam tek kad prođu karantin 14 dana, šta sad treba da mi ubace virus među 585000ljudi, ma važi 
2. E pa videli smo sneg u maju, sad ćemo „grad bez ljudi,, ok Severina sve si u pravu, ubedila si nas

3. - kako se zove penzos koji prekrši zabranu? walking ded. jel bilo?

4. Sezona 2020 je lošija od zadnje sezone gejm of trones

5. Penzionere hvataju po ulici ko pokemon 


\section{DISASTER HUMOR AND INTERNET MEMES DURING THE CORONAVIRUS PANDEMIC ON THE EXAMPLE OF TWO INSTAGRAM PROFILES}

\begin{tabular}{c} 
Abstract \\
\hline Željko PREDOJEVIĆ \\
Comenius University in Bratislava \\
Faculty of Arts \\
Gondova 2 \\
SK - 81102 Bratislava \\
zeljko.predojevic@uniba.sk
\end{tabular}

The article discusses the issue of the humorous discourse of Internet memes that emerged in response to the coronavirus (COVID-19) pandemic. Memes are studied within digital folklore as virtual surrogates of disaster jokes, the genre with which they have many similarities. They appeared immediately after the virus began spreading, thematizing the pandemic and new life situations caused by it, and are greatly influenced by media reports about the virus and its spreading. This article aims to analyze the humorous discourse of Internet memes, which is divided into four groups motivated by the way they approach the topic of the virus and the pandemic, and consequently they achieve a humorous effect compared to disaster jokes. The research is focused on internet memes posted on two Instagram profiles: eroGAG and Gospodar Pršljenova. The memes were posted at the beginning of the pandemic in Europe, in March and April 2020.

Keywords: humor, disaster jokes, internet memes, digital folklore, netlore, coronavirus, COVID-19, pandemic, eroGAG, Gospodar Pršljenova 